\title{
Challenges in Teaching English for the Deaf Students
}

\author{
Aris Ristiani \\ Universitas Muhammadiyah Malang \\ (arisristiani9@gmail.com)
}

\begin{abstract}
English is a subject included in the education curriculum in Indonesia. According to the individuals with Disabilities Education Act (IDEA), one of the categories of students with special needs is deaf students. This paper is aimed to discover the challenges faced by deaf students' teachers in teaching English and the strategies to cope with those challenges based on relevant theories and previous studies. The finding showed that teachers experienced several challenges in teaching the deaf students such as getting students' attention, understanding words from students' lip movements, giving definitions and example, differentiating similar words in different contexts, and delivering materials related to students prior knowledge. The strategies to cope those challenges are asking students to prepare dictionaries, using alphabetic signs, waving or patting students' shoulders to get their attention. In addition it also requires teaching model and professional teacher to be creative and effective in teaching English for the deaf students.
\end{abstract}

Keywords: special school, deaf students, challenge.

The government of Republic of Indonesia established special schools for students with special needs, based on Law No 72 of 1991 where it is stated that every child with disability has the right to pursue for education. SLB serves and helps the special need students with the facilities to develop their language growth, culture, and behavior. Based on article 16 of Law 72 of 1991, the curriculum of special school is similar to regular school in Indonesia with some adaptation in regard to the students' need.

A special school is school which is specifically designed to serve and support the students' need in education. This school is designed to help the students with special needs to achieve a higher level of personal self-sufficiency and success in school and their community which may not be available if the student were only given access to a typical classroom education.

As UNESCO (2011), Revision of the International Standard Classification of Education (ISCED) stated that Special Education Needs is

"Education designed to facilitate the learning of individuals who, for a wide variety of reasons, require additional support and adaptive pedagogical methods in order to participate and meet learning objectives in an educational programme. Reasons may include (but are not limited to) disadvantages in physical,behavioural, intellectual, emotional and social capacities. Educational programmes in special needs education may follow a similar curriculum as that offered in the parallel regular 
education system, however they take individuals' particular needs into account by providing specific resources (e.g. specially trained personnel, equipment, or space) and, if appropriate, modified educational content or learning objectives. These programmes can be offered for individual learners within already existing educational programmes, or be offered as a separate class in the same or separate educational institutions". (p. 83)

Furthermore, Redbridge (2014) stated that special education refers to an education for students with special needs with an environment that could facilitate the students with special needs.

Hearing Impairment or deaf is a general term indicating a disability that may vary in severity from mild to profound (Kirk, 1992). They have limited ability to hear. Some hearing impaired students have mild hearing loss and may be able to use hearing aids to amplify sounds, while others have no sound perception in one or both ears. They may be born deaf or may develop hearing loss from disease, aging, and exposure to noise, or trauma. Like a normally student, the deaf student needs to develop their language for their social life and their knowledge.

In Indonesia, based on article 16 of Law 72 of 1991, the curriculum of special school is similar to regular school with adaptation based on the students' need. It is quite difficult for them to learn English because deaf and hearing impaired students tend to be visual learners and this is difficult in an environment where much essential information is delivered exclusively by word of mouth (Oyewumi, 2008). They cannot understand clearly information by sound caused their reading ability are lack of vocabularies. The deaf students often show significant delays in phoneme production, vocabulary, and syntax (Cawthon, 2001).

The deaf and hard-of-hearing children would need language assistance just like persons who show a severe disability in mobility need so-called personal assistance. Easterbrook (2013) stated that the deaf students need to access the language, literacy interactions, and curriculum and material. Educators face challenges in all of these areas. For the deaf or hard-of hearing, communication is daily challenge. Learning an additional language, especially in a foreign country, is more difficult for learners who do not have a strong base in their first language. The students use lips reading or sign language or finger spelling for communication in addition to print and visuals. Deaf students cannot fully process the information in the form of sounds, while the normal students can process them. Hence, it becomes a challenge for teachers to teach English for the deaf. The teachers need to have special considerations to adjust to students' disabilities of their behaviors (Mpofu, et al., 2013).

\section{The Challenge of Teaching English for Deaf Student}

There are eight several challenges in teaching deaf students. A study conducted by Adi, et. all in 2017 revealed eight (8) findings: the first challenge was that the teachers needed to adapt the material and media. The students' disability to hear any materials and media in the form of audio or sounds made the teachers needed to adapt and deliver the materials in appropriate ways with the right media. The second challenge was that the teachers faced difficulties in finding the appropriate media for the students. Weber (2016) stated that often school are not capable of supplying their deaf students with the proper technology that could significantly increase the learning development process. This could be any forms of assistive technology; whiteboards, chat room, strobelights, digital pen technology, closed captioning on all movies and videos, infra-red system hearing aid compatible, computer assisted note taking, videos for testing materials, alert systems such as vibrating systems, and alarms and interpreters in the classroom. 
The third challenge was that sometimes the students made mistakes in understanding words because of similar lip movements to other words, and it was also hard for them to guess the words the teacher said because they only saw the lip movements, and they could not hear the teacher's voice. The fourth challenge was to get the students' attention without calling their names. This was found to be a great challenge to get the students' attention without calling their name for they will not be able to hear what the teacher said. In this case, the teachers might need to have some sort of tricks to get them focused to the teacher. The fifth challenge was the students' limited vocabularies; the teacher first needs to give definitions and examples of words before continuing the next materials. The sixth challenge was the lack of background knowledge which influences the students in learning the material. The seventh challenge was the students' difficulties in differentiating similar words. The eight and the last challenge was need of repetition in delivering the material. This was due to the students' minimum capacity of the target language being learned. The more repetition held the better the learning outcome is expected to reach.

Another finding was in term of vocabulary, Domagala-Zysk (2016) stated that deaf students usually have some problems in learning foreign vocabulary and this is mostly connected with their difficulties in mastering the spoken language. Psycholinguistic studies showed that deaf children who possess the same level of intellectual potential as their hearing peers usually get lower results in vocabulary tests (Lederberg, 2005) and the deaf students have difficulties with the fluency of vocabulary-related memory operations. In addition, Rudelic (2012) found that in teaching deaf students, the teacher are not professionally prepared or educated to teach deaf students. The lack of information and training leaves teachers ill prepared to teach the deaf students. Beveridge (1999) stated that the deaf students require special services which must be offered by qualified and skilled teacher in order to respond to their unique needs. Weber (2016) stated that every child learns differently. Even if teachers are given instruction on how to best assist one of their deaf students, it could be totally different for the next, resulting in an academic gap. Besides, El-Zraigat and al-Emam (2005) showed Problems faced by student who are deaf and hard-of hearing revealed that students with hearing loss suffer from communication, academic, social, emotional, and family problems. It caused that deaf student to be lack of hearing and when they learn about language, it requires different ways from learning other subjects (Domagala, 2015).

\section{The strategies to cope the challenges}

Further, Adi et al. (2017) described the teacher efforts to face the challenges in teaching English for deaf students. First, to cope with teaching materials problem, the teacher needed to adapt the material and media. This can be done by looking for references on different kinds of media possible to be used in teaching deaf students. Second, to cope with teacher's difficulties in finding appropriate media for students is by looking at many references of good materials from books and the Internet. Having more references can help to broaden the teachers' views and ideas on how to vary teaching. Third, to help students avoiding mistakes in understanding words due to similar lip movements to other words, teacher needs to write down the word on the white board and use alphabetic sign language to help them to understand the words the teacher said. This can at least minimize the mistakes to students may make during the learning of foreign language. Fourth, to face the challenge in managing students' attention without calling their names is the teacher knocked the table off to capture the students' attention. This might be one of the tricks the teacher can apply in getting their students' attention. Fifth, related to students' limited vocabularies, teachers asked students to always bring dictionaries for both English 
and Indonesian to help them with their limited vocabularies.

The sixth effort to face the challenge about the students' lack of background knowledge is giving the student assignment and lots of examples related to their real life. The seventh strategy to minimize students' difficulties in differentiating similar words is giving the examples for each word, and made a comparison to help students understand the differences of contexts. And the last effort in terms of repetition in delivering the material, they need to be patient a lot in the teaching and learning process in the class.

Moreover, in term of vocabulary, Domagala-Zysk (2013) added that deaf students should be made aware that while learning a foreign language they should personalize their foreign vocabulary and learn those words and expressions which they are sure will be useful to them. The second strategy might be named Vocabulary Emotionalization. Linguists agree that words that were presented not only clearly, but also with an emotional component (Kaczmarek, 2001). The third is Word Semantic Analysis and Word Morphological Analysis. Having these strategies should help teachers to effort out their own creative and effective methodological tools that may motivate their deaf students and maintain them in consistent, systematic and successful foreign language learning.

In teaching deaf, it can also be supported by teaching model beneficial for deaf students called as the person-centered model. The person-centered model for deaf students views the student as an individual, the specific learning style of the student, and the specific language needs of the student (Ewing \& Jones, 2003). Drigas, Kouremenos and Vrettaros (2006) stated that classroom needs model of the visual for using video conference service through images, realization of cooperative the real time activities to supported self-learning.

Furthermore, to develop the teacher's professional in teaching English, Kodiango and Syomwene (2016) recommended that teacher should train the learners to develop good handwriting, master correct spellings and acquire adequate vocabulary for effective composition writing. It means that teaching English does not only encourage deaf student about speaking and understanding language, but they should learned about writing text as well.

\section{Conclusion}

Based on some aforementioned studies, it can be concluded that there are numbers of challenges in teaching English for the deaf students. Those challenges include the teachers' need to adapt the material and media appropriate for teaching, students make mistakes in understanding words due to their limited vocabulary mastery, teacher's difficulty to get the students' attention, student limited mastery in vocabulary, teachers are not professional, and the need of repetition in delivering the material taught to the deaf students. Meanwhile, the strategies to cope the challenges are: a) the teacher need a lot of references to developing the materials, b) the teacher need media and write the words on the white board, c) knocking the table to get deaf students' attention, d) asking the deaf student to bringing dictionary, e) giving homework and a lot of example, f) need teaching model and professional teacher to be creative and effective in teaching English for the deaf students.

\section{References}

Adi, et al. (2017). Teaching special students: English lesson for deaf students in Indonesia special Junior High School. International Journal of Education and Research. 15 (12).

Beveridge, S. (1999). Special educational need in schools. London: Roughtledge.

Cawthon, Stephanie W. (2001). Teaching 
Strategies in Inclusive Classrooms With DeafStudents. University of WisconsinMadison. Oxford Press.

Domagala, E. (2015). Teaching English as a Second Language to Deaf and Hard-of Hearing Students. The Oxford Handbook of DeafStudies in Language. DOI: 10.1093/ okfordhb/9780190241414.013.15

Drigas, A. Kouremenos, D and Vrettaros, J. (2006). Teaching of English to Hearing Impaired Individuals Whose Mother Language is the Sign Language. Agia Paraskevi, 153 10, Athens, Greece.

Domagała-Zyśk, E. (2013a). Wielojęzyczni. Studenci niestyszacy $i$ stabostyszacy $w$ procesie uczenia się nauczania języków obcych [Multilingual. Deaf and hard-ofhearing students in the process of learning and teaching foreign languages]. Lublin: Wydawnictwo KUL.

Easterbrooks, S. \& Beal-Alvarez, J. (2013). Literacy instruction for students who are deaf and hard of hearing. New York: Oxford University Press.

El-Zraigat, I and Al-Emam, M. (2005). The Problem of students who are deaf and hard-of-hearing ad its relation to some variables. Journal offaculty of Education/ Al-Massorah University, 2(58), p. 155181.

Ewing, K. M., \& Jones, T. W. (2003). An educational rationale for deaf students with multiple disabilities. American Annals of the Deaf, 148, 267-271. doi:10.1353/aad.2003.0019

OECD Child well-being Module www.oecd. org/els/social/family/database/CWBM

OECD - Social Policy Division - Directorate of Employment, Labour and Social Affairs 1Updated 14 May 2012

CX3.1 Special Educational Needs (SEN)

Kodiango, William O. Syomwene, A. (2016). Challenges faced by the hearing impaired learners in composition writing and answering comprehension questins in English language lessons. Open access Publishing. 2(10)

Krik, S.A. (1992). Educating Exception Children (2nd Ed). Boston: Houghton Milan.Co

Mpofu, J. \&Chimenga, S. (2013). Challenge face by Hearing Impaired pupil in learning: A case study of King George VI Memorial School. IOSR Journal of Research \& Method in Education (IOSRJRME). 2 (1), 69-74

Oyewumi, A. (2008). An investigation on inclusive instructional practices and learning of students with hearing impairments in post-secondary schools. African Journal of Cross-Cultural Psychology and Sport Facilitation 10 158-169 DOI: dx.doi.org/10.4314/ajcpsf. v10i1.37622

Redbridge. Special Education Needs.Family Services Directory. Retrieved November 12, 2015 from http://redbridge.gov.uk/ special_education_needs.html.

Rudelic, Adrienne.(2012). An Analysis of teaching methods for children who are deaf with multiple disabilities. Independent Studies and Capstones. Washington University School of Medicine.

Weber, Marilyn (2016). 10 Challenges deaf students face in the classroom. gettingsmart.com. accessed on Dec, 26th 2018 . 